\title{
KONSTRUKSI KEISTIMEWAAN YOGYAKARTA DALAM NARASI FILM-FILM KOMPETISI PRODUKSI DINAS KEBUDAYAAN YOGYAKARTA 2016-2017
}

\author{
Lilik Kustanto \\ Rr. Ari Prasetyowati \\ Ozhara Aisyia \\ Jurusan Televisi, Fakultas Seni Media Rekam, ISI Yogyakarta \\ Jalan Parangtritis Km 6,5 Sewon, Bantul, Yogyakarta \\ No. Hp.:+62818264843,+6287828168395,E-mail: ari_pras80@yahoo.com, elbaraja9@gmail.com
}

\begin{abstract}
ABSTRAK
Sejak Undang-Undang Keistimewaan disahkan, Dinas Kebudayaan Daerah Istimewa Yogyakarta (DIY) konsisten menggelar program kompetisi Pendanaan Pembuatan Film. Dalam genre fiksi dan dokumenter, film-film terpilih yang difasilitasi telah menafsirkan dinamika kebudayaan di DIY dengan cukup beragam. Asumsinya, film-film tersebut setidaknya mampu mewujudkan tata nilai budaya masyarakat yang berbasis pada nilai-nilai luhur budaya lokal. Namun, beragamnya perspektif dan pendekatan yang digunakan sineas dalam produksi film kompetisi tentunya membangun realita baru akan narasi keistimewaan Yogyakarta. Penelitian ini akan memeriksa bagaimana konstruksi keistimewaan DIY dibangun lewat narasi film-film pemenang kompetisi tahun 2016-2017. Proses penelitian saat ini telah mencapai tahapan analisis struktur luar narasi kedua film kompetisi produksi Danais 2016-2017. Adanya ketidaksesuaian struktur narasi film-film dengan gagasan yang digunakan untuk menemukan struktur luar menurut Todorov, justru menjadi tantangan besar dalam penelitian ini. Ketidaksesuaian ini sekaligus menjadi suatu penemuan yang penting saat keseluruhan proses analisis terselesaikan.
\end{abstract}

Kata kunci: naratif, konstruksi keistimewaan, film kompetisi Danais

\section{ABSTRACT}

Construction of the Specialty of Yogyakarta in the Narrative of Film Making Competition Produced by the Culture Office of Yogyakarta in 2016-2017. Since the Constitution of the Specialty was legitimated, the Culture Office of the Special Region of Yogyakarta has been consistently holding a film-making funding program. In the genres of fiction and documentary, the facilitated selected films have interpreted the cultural dynamics in the Special Region of Yogyakarta with quite a variety. The assumption is that those films are at least able to realize the cultural values of the society based on the sublime values of the local culture. However, the variety of perspectives and approaches used by filmmakers in the production of film making competition certainly builds a new reality of the narrative of Yogyakarta's specialty. This research will examine how the construction of the specialty of the Special Region of Yogyakarta is built through the narrative of the winning films in the competition in the past two years between 2016-2017. The current research process has reached the stage of analysis of the external structure of two competitive films produced by Danais in 2016-2017. According to Todorov, the inconsistency in the narrative structure of the films with the ideas used to find the external structure has become a major challenge in this research. This discrepancy will also have become an important discovery when the entire analysis process is resolved.

Keywords: narrative, construction of specialty, Danais Film Competition 


\section{PENDAHULUAN}

Sejak Undang-Undang Keistimewaan disahkan, Dinas Kebudayaan Daerah Istimewa Yogyakarta (DIY) konsisten menggelar program kompetisi Pendanaan Pembuatan Film. Pendanaan ini ditujukan untuk memfasilitasi para pembuat film Yogyakarta dan sineas dari daerah lainnya untuk bisa berkreasi dan berkarya di bidang film, baik fiksi maupun dokumenter. Dalam regulasi pengajuan proposal, tertulis bahwa perencanaan film haruslah memuat latar belakang dinamika kebudayaan di DIY. Hal tersebut dapat dikenali melalui indikatorindikator: (a) ruang, antara lain geografis, sosial, ataupun budaya; (b) karakter manusia di Yogyakarta, antara lain cara manusia hidup, bersosialisasi, dan bertahan di Yogyakarta; (c) penguasaan atmosfer sosial-budaya di Yogyakarta; dan (d) ketepatan memilih isu tematik untuk diangkat ke dalam film.

Dalam genre fiksi dan dokumenter, filmfilm terpilih yang difasilitasi telah menafsirkan dinamika kebudayaan di DIY dengan cukup beragam. Asumsinya, film-film tersebut setidaknya mampu mewujudkan tata nilai budaya masyarakat yang berbasis pada nilainilai luhur budaya lokal. Asumsi ini muncul melalui rujukan visi Dinas Kebudayaan DIY sebagai pemrakarsa kompetisi. Dengan misi melestarikan, melindungi, dan mengembangkan aset budaya DIY sebagai upaya mewujudkan jati diri masyarakat serta menjadikan ketahanan budaya sebagai jiwa dan semangat pemerintahan yang katalistik, harapannya DIY dapat menjadi pusat budaya dengan berbagai event budaya nasional dan internasional.

Kerangka visi dan misi Dinas Kebudayaan DIY serta latar belakang dinamika kebudayaan DIY digunakan sebagai asumsi awal penelitian ini. Namun, beragamnya perspektif dan pendekatan yang digunakan sineas dalam produksi film kompetisi tentunya membangun realita baru tentang narasi keistimewaan Yogyakarta. Penelitian ini akan memeriksa bagaimana konstruksi keistimewaan DIY dibagun lewat narasi film-film pemenang kompetisi pada 2016-2017.

Dari uraian latar belakang tersebut, penelitian ini mencoba untuk menjawab pertanyaan apa narasi film-film produksi Dinas Kebudayaan DIY pada 2016-2017, apa saja konstruksi keistimewaan yang dapat terbaca dari narasi film-film tersebut, dan bagaimana narasi film-film tersebut dapat mengonstruksi keistimewaan Yogyakarta.

\section{TINJAUAN PUSTAKA}

\section{Penelitian Terdahulu}

Kajian "Pemetaan Pembuat Film Yogyakarta 2015" oleh Saputro dalam Suwarto et. al. (2015) menunjukkan bahwa karakter pembuatan film di DIY dapat dimodelkan dalam kerangka matriks berbasis sumbu hubungan permodalan dan hubungan kerja. Setiap kuadran menggambarkan letak tiap-tiap kelompok film sesuai tipe mekanisme pembuatan film mereka dilihat dari segi hubungan dengan pendana dan hubungan dengan kru produksi. Dengan begitu, terdapat empat tipe, yaitu kuadran teman-modal (A), modal-pekerja (B), pekerja-hibah (C), dan hibah-teman (D).

Penelitian tersebut -yang juga didanai oleh Danais - dapat digunakan sebagai pijakan dalam penelitian ini untuk melihat bagaimana pola, latar belakang, dan gejala kerja para pembuat film DIY. Hal ini penting mengingat salah satu syarat mengikuti kompetisi produksi ini adalah warga DIY. Kajian ini juga menjadi awalan dalam pembangunan perkembangan film DIY. Namun, kajian ini masih terbatas pada apa 
dan siapa pembuat film di Yogyakarta, belum ada kajian telaah mendalam terkait bagaimana film-film yang diproduksi para pembuat tersebut dan apa signifikansinya terhadap perkembangan perfilman DIY. Padahal, tidak bisa dipungkiri bahwa adanya skema kompetisi pendanaan produksi film ini telah meningkatkan animo produksi insan perfilman DIY. Meski tidak serta merta mencipta 'pasar' perfilman, geliat produktivitas film di DIY setelah disahkannya Undang-Undang Keistimewaan meningkat drastis.

Dalam buku Krisis dan Paradoks Film Indonesia (Nugroho \& Herlina, 2015) Yogyakarta muncul sebagai latar perkembangan film nasional yang penting untuk dicatat. Meski tidak spesifik melihat bagaimana dinamika konstelasi politik di Yogyakarta lewat perfilmannya, buku ini dapat menjadi latar bagaimana Yogyakarta sebagai kota pemerintahan dan budaya bernegosiasi dengan film sebagai produk budaya, meski tidak signifikan. Dari rangkaian pustaka yang disajikan, dapat disimpulkan bahwa belum ada satu pun kajian yang melakukan penelitian dengan objek dan perspektif serupa. Hal ini merupakan alasan mengapa penelitian ini layak untuk dilakukan.

Argumen dalam buku Contemporary Indonesian Film oleh van Harren, 2012:6) bahwa praktik naratif dalam film adalah komponan dari praktik diskursus yang berhubungan dengan bentuk dan konten dari teks film. Praktik naratif adalah tentang cerita dan bagaimana cerita itu diceritakan lewat media audiovisual di antara konteks relasi kekuasaan. Relasi kekuasaan ini melibatkan kedua kekuasaan aktual dari negara dalam kontrolnya terhadap media massa lewat sistem sensor, penyiaran dan kebijakan pers dan lewat kepemilikan dan kontrol industri dan institusi media swasta nasional dan transnasional. Van Harren juga mempertanyakan ulang tentang konsepsi sinema nasional yang tunggal di tengah iklim transnasional ini. Konstruksi dan perubahan makna dan praktik dalam film naratif ini tidak serta muncul begitu saja, namun juga dipengaruhi oleh negara dan politik dominan yang dianut negara. Dalam penelitian ini, pemikiran Harren melatarbelakangi bagaimana narasi yang tercipta dalam produksi film-film kompetisi Dinas Kebudayaan DIY dipengaruhi oleh institusi dan politik dominan yang dianut negara dalam konteks daerah istimewa.

Dalam buku What's "oppositional" in Indonesian Cinema? dalam Rethinking Third Cinema, Krishna Sen dalam Guneratne et.al. (2004) menjelaskan bahwa di Indonesia, gagasan lokalitas sebagai situs figuratif perlawanan sering tidak didefinisikan sebagai oposisi terhadap budaya transnasional atau globalisme, melainkan dalam hal konstelasi politik di dalam bangsa. Argumentasi ini penting mengingat norma agama dan kemasyarakatan yang kental dalam produksi film-film kompetisi Dinas Kebudayaan DIY merupakan gagasan lokalitas yang bisa dianggap sebagai perlawanan konstelasi politik dominan di negara ini.

$$
\text { Penelitian "Analisis Naratif: }
$$

Kemiskinan dalam Program Reality TV "Pemberian Misterius" di Stasiun SCTV oleh Kustanto (2015) menggunakan metodologi dan konstruksi pemikiran yang sama dengan penelitian terdahulu dengan subjek yang berbeda. Analisis naratif sebagai metode dalam penelitian ini digunakan untuk membantu memahami, menganalisis, dan mengevaluasi sebuah kisah. Penelitian terdahulu ini menggunakan metode analisis naratif yang dikembangkan oleh Tzvetan Todorov dengan 
struktur narasinya dan Levi Strauss dengan oposisi biner dalam narasi. Penelitian terdahulu ini penting untuk membuktikan bahwa teori naratif dari dua pemikir tersebut masih mampu digunakan sebagai pisau analisa dengan objek baru yang membangun perspektif kritis dalam narasi dominan yang dibentuk negara.

\section{Landasan Teori}

Bagian penting dalam pengumpulan data naratif adalah cerita (story) dan alur cerita (plot). Kedua aspek ini penting dalam memahami suatu narasi, bagaimana narasi bekerja, bagian mana dari suatu peristiwa yang ditampilkan dalam narasi dan bagian mana yang tidak ditampilkan. Di dalam narasi, terdapat dua aspek, yakni (a) waktu yang terdiri dari elemen; durasi, urutan, dan frekuensi, serta (b) ruang (Bordwell \& Thompson, 2013:73). Narasi tidak identik dengan peristiwa aktual karena pembuat narasi bukan hanya memilih peristiwa yang dipandang penting, tetapi juga menyusun peristiwa tersebut ke dalam babak atau tahapan tertentu. Karakteristik lain dari narasi adalah struktur bercerita. Tahapan atau struktur narasi adalah cara pembuat narasi menghadirkan peristiwa kepada khalayak. Peristiwa tidak dilihat secara acak, tetapi tersusun lewat suatu struktur atau tahapan tertentu. Salah satu pemikir yang menemukan bagaimana narasi dapat membentuk struktur tertentu diajukan oleh Tzvetan Todorov. Todorov (1975:98) mengungkapkan bahwa struktur sebuah narasi selalu berawal dari ekuilibrium (keseimbangan), kemudian berkembang menjadi gangguan (kekacauan) dan diakhiri dengan kembali lagi pada ekuilibrium (keseimbangan).

Struktur narasi yang telah dibahas bisa disebut struktur luar. Disebut struktur luar karena rangkaian tersebut (dari eksposisi hingga klimaks) bisa diamati secara eksplisit dalam suatu narasi. Selain struktur luar, ada yang disebut sebagai struktur dalam. Struktur luar sudah direncakan oleh pembuat teks, dalam hal ini pembuat film. Sementara struktur dalam umumnya tidak disadari oleh pembuat teks. Struktur dalam itu baru ditemukan setelah dibedah dan dianalisis. Salah satu cara untuk mengetahui struktur dalam dari suatu narasi diperkenalkan oleh Claude LeviStrauss mengenai oposisi biner. Levi-Strauss setidaknya menggunakan dua konsep penting, pertama konsep pembedaan (diferensiasi), yaitu satu kata dengan kata lain memiliki diferensiasi sistematis yang ada antara setiap kata dengan kata-kata lain. Diferensiasi yang terdapat dalam setiap kata adalah sistematis sifatnya karena dikontrol oleh bahasa. Bahasa pada dasarnya adalah seperangkat perbedaanperbedaan. Kedua, konsep tentang sintagmatik dan paradigmatik (Ahimsa-Putra, 2001).

\section{METODE PENELITIAN}

Materi penelitian ini adalah film fiksi dan dokumenter yang diproduksi oleh Danais dalam kurun waktu 2016-2017. Selama kurun waktu tersebut, telah diproduksi 15 film. Dari kelima belas daftar film tersebut, film dokumenter tidak diikutsertakan sebagai objek penelitian dengan pertimbangan bahwa analisis naratif dapat lebih tepat digunakan dalam filmfilm naratif. Bukan berarti film-film dokumenter tidak memiliki unsur naratif, namun sejak naratif identik dengan ilmu penceritaan, maka hal ini dianggap tidak terlalu relevan dalam film-film non naratif. Dari jumlah populasi tersebut, dipilih sebuah film dalam setiap tahun (2016-2017). Pemilihan ini dilakukan dengan pertimbangan bahwa film-film tersebut telah mendapatkan pengakuan dari beberapa festival 
kenamaan: Festival Film Indonesia (FFI), Jogja NETPAC Asian Film Festival (JAFF), dan Apresiasi Film Indonesia (AFI). Artinya, kedua film pilihan telah menjumpai penontonnya lebih sering dibanding film-film lain. Hal ini secara tidak langsung mengarahkan apresiasi penonton terhadap film produksi Danais.

Adapun objek dalam penelitian ini meliputi dua film fiksi yang diproduksi dalam kurun waktu 2016-2017. Detail dua film tersebut adalah sebagai berikut.

1. "Munggah Kaji" | Sutradara: Rivandy Adi Kuswara | Produksi 2017

Di sebuah desa di bawah lereng Gunung Merapi, seorang perempuan bernama Wening (80) sedang mempersiapkan keberangkatan haji. Keberangkatannya kali ini sudah direncanakan sejak lama untuk menggantikan Darmi, teman dekatnya yang tidak dapat melakukan keberangkatan haji sendiri. Menjelang hari keberangkatan, keluarga Darmi melakukan ritual pembacaan dan doa. Sayangnya suami Wening yang bernama Kusmin, membuat dia tidak nyaman pergi berziarah.

2. "Ruah" | Sutradara: Makbul Mubarak | Produksi 2016

Halim Hardiyanto adalah seorang tokoh masyarakat yang rajin beribadah dan bersedekah. Ia yang sudah beristri bermaksud menikahi seorang wanita yang jauh lebih muda dari dirinya untuk tujuan ibadah. Akan tetapi, istrinya tidak setuju dan menyumpahi Halim jika nekat menikah lagi. Kemalangan dan kejadian aneh berduyun-duyun datang setelah Halim menikahi Mega, wanita muda itu.
Penelitian ini akan melihat bagaimana konstruksi keistimewaan dalam analisis naratif pada film-film kompetisi produksi Dinas Kebudayaan DIY pada kurun waktu 2016-2017. Konstruksi keistimewaan adalah temuan yang ingin dicapai dari penelitian ini. Untuk mendapatkan konstruksi tertentu, terlebih dahulu penelitian ini akan melakukan metode analisis naratif pada narasi film-film pilihan. Hipotesis awal penelitian ini adalah terbentuknya konstruksi keistimewaan dalam narasi film-film kompetisi yang didukung oleh Danais. Analisis naratif digunakan untuk menguji hipotesis ini dalam sistematika berpikir yang struktural dan empiris.

Analisis naratif digunakan untuk menempatkanteks sebagaisebuahcerita(narasi). Teks dilihat sebagai rangkaian peristiwa, logika, dan tata urutan peristiwa, bagian dari peristiwa yang dipilih dan dibuang. Pembuat teks disadari atau tidak menyusun teks ke dalam tahapan atau struktur tertentu, sebaliknya khalayak juga akan membaca narasi berdasarkan tahapan atau struktur tersebut. Menurut Todorov (1975:98), suatu narasi mempunyai struktur dari awal hingga akhir. Narasi dimulai dari adanya keseimbangan yang kemudian terganggu oleh adanya kekuatan jahat. Narasi diakhiri oleh upaya untuk menghentikan gangguan sehingga keseimbangan kembali tercipta.

Struktur narasi yang telah dibahas Todorov dapat disebut struktur luar karena rangkaian tersebut (dari eksposisi hingga klimaks) bisa diamati secara eksplisit dalam suatu narasi. Selain struktur luar, ada yang disebut sebagai struktur dalam. Struktur ini tidak terlihat secara nyata dan baru ditemukan oleh peneliti setelah peneliti membongkar dan meneliti relasi dari rangkaian cerita tersebut. Salah satu cara untuk mengetahui struktur dalam 
dari suatu narasi diperkenalkan oleh Claude Levi-Strauss mengenai oposisi biner (Eriyanto, 2013:161). Strauss juga mengenalkan konsep tentang sintagmatik dan paradigmatik. Katakata memiliki relasi dengan kata lain sehingga membentuk suatu pengertian melalui hubungan asosiatif (paradigmatik) dan hubungan sintagmatik. Hubungan sintagmatik adalah hubungan antara suatu tanda dengan tanda lain dalam satu kesatuan (linear). Sementara hubungan paradigmatik adalah relasi antara tanda-tanda dalam suatu paradigma (kesamaan umum): unit-unit memiliki kesamaan karakteristik yang menentukan keanggotaannya dalam paradigma tersebut.

Menurut Levi-Strauss, relasi-relasi yang berada pada stuktur dalam dapat disederhanakan lagi menjadi oposisi berpasangan. Oposisi biner adalah aspek paling penting yang bisa menyingkap bagaimana manusia berpikir, bagaimana manusia memproduksi makna dan memahami realitas. Oposisi biner dalam narasi ini bisa mengungkapkan makna-makna di balik suatu cerita, logika di balik cerita (Eriyanto, 2013:166).

Dari uraian tersebut, didapatkan alur metodologi penelitian ini. Pertama, setiap film dalam akan diamati bagaimana cerita (story) dan plotnya, untuk kemudian mencari struktur narasi. Di bagian selanjutnya, analisis akan dilakukan secara sintagmatik lalu dilanjutkan dengan paradigmatik sehingga peneliti dapat melakukan pengujian dengan oposisi biner. Untuk dapat menjawab pertanyaan penelitian ini, dibutuhkan pemahaman intertekstualitas karena sebagai sebuah teks, narasi selalu berkaitan dengan teks-teks lain. Keterkaitan antara satu teks dan teks yang lain inilah yang dapat memeriksa konstruksi semacam apa yang coba dibangun lewat teks film-film kompetisi.

\section{HASIL PENELITIAN DAN PEMBAHASAN} Story \& Plot Munggah Kaji \& Ruah

Analisis terhadap cerita dan alur (plot) film "Munggah Kaji" memperlihatkanadanya kemiripan. Alur (plot) ditampilkan secara kronologis meski tidak benar-benar lengkap memberikan petunjuk keseluruhan cerita. Bahkan, dalamplotterdapatbeberapakaliadegan yang menunjukkan kesamaan pemahaman cerita. Meski terdapat kemiripan, keseluruhan peristiwa tidak sepenuhnya ditunjukkan dalam alur film ini. Alur tidak menampilkan apa yang sebelumnya terjadi antara Mbah Darmi dan Mbah Wening. Berpusatnya film ini pada satu karakter saja, Mbah Wening membuat informasi dari karakter lain terbatas.

Berbeda dengan "Munggah Kaji", "Ruah" merupakan film yang ceritanya tidak mudah untuk ditelusuri. Hal ini terjadi karena film ini menggunakan banyak simbol, kejadian tidak masuk akal dan seringkali tidak ditemukan relasi sebab akibatnya dalam dunia empiris. Analisis terhadap cerita dan alur (plot) film "Ruah" memperlihatkan adanya perbedaan, di mana presentasi alur tidak sama dengan cerita yang ingin disampaikan. Hal ini dapat ditemui terutama pada adegan yang janggal setelah istri Halim masuk rumah sakit. Kejanggalan tersebut semakin jelas karena tidak adanya perbedaan ruang dan waktu yang signifikan sepanjang alur berjalan sehingga film ini sangat berpotensi mengecoh pemahaman cerita.

\section{Struktur Narasi "Munggah Kaji" dan "Ruah"}

Dari uraian hasil analisis story dan plot didapat struktur luar dari sebuah narasi yang akan dilakukan lewat pendekatan gagasan Todorov yang terdiri dari ekuilibrium (keseimbangan), ganguan (kekacauan) dan kembali lagi ke posisi 
ekuilibrium (keseimbangan). Namun, dari analisis cerita didapatkan bahwa pada usaha pemulihan menuju keseimbangan (ekuilibrium) di akhir, kedua film menunjukkan hasil yang lain. Terbatasnya plot yang disajikan membuat kegagalan interpretasi cerita terkait bagaimana cerita kembali ke titik keseimbangan. Hal ini terutama dapat jelas terlihat pada film "Munggah Kaji", sedangkan dalam film "Ruah", akhir plot disajikan dengan Halim yang meronta saat diikat. Adegan ini membangun interpretasi bahwa kekacauan yang muncul sebelumnya memang berhasil diselesaikan, namun tidak serta merta membawa pemulihan keteraturan kembali seperti apa yang pemikir naratif utarakan.

\section{Oposisi Biner dalam Narasi "Munggah}

\section{Kaji" dan "Ruah"}

Untuk keperluan analisis, penelitian ini membagi susunan miteme ke dalam beberapa aspek. Aspek yang akan dibahas dalam subab ini dibagi berdasarkan struktur cerita (bukan plot) berdasarkan pemikiran utara Todorov (1975), yaitu:

Ekuilibrium (keseimbangan) $\Longrightarrow$ Gangguan (kekacauan) $\Longrightarrow$ Ekuilibrium (keseimbangan)

Pada struktur ekuilibrium pertama, berikut adalah susunan miteme secara sintagmatik dan paradigmatik.

Tabel 1 Sintagmatik \& Paradigmatik Ekulibrium 1

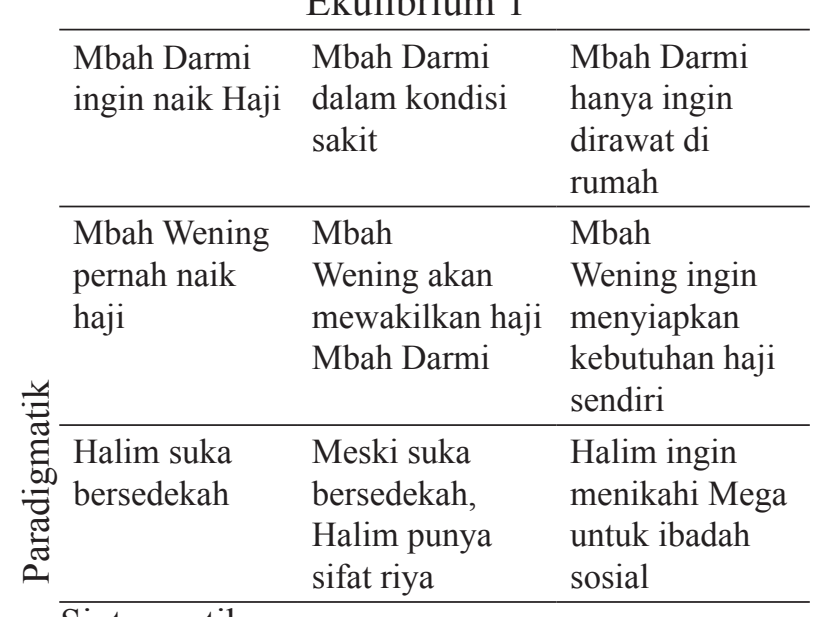

Sintagmatik aspek ini.

Berikut merupakan oposisi biner pada

Tabel 2 Oposisi Biner Ekulibrium 1

\begin{tabular}{|c|c|c|c|c|}
\hline Wening (W) & istri & \multirow{3}{*}{$\begin{array}{c}\text { Suka } \\
\text { beribadah }\end{array}$} & mampu & $\begin{array}{l}\text { Firasat } \\
\text { tidak } \\
\text { kembali }\end{array}$ \\
\hline Darmi (D) & kerabat & & sakit & $\begin{array}{l}\text { Firasat } \\
\text { mati }\end{array}$ \\
\hline $\operatorname{Halim}(\mathrm{H})$ & suami & & riya' & $\begin{array}{l}\text { Poligami } \\
\text { utk ibadah } \\
\text { sosial }\end{array}$ \\
\hline
\end{tabular}

Dalam tabel 2 dapat diketahui bahwa ketiga karakter sama-sama senang beribadah meski kondisinya berbeda. Oposisi paling terlihat adalah peran Mbah Wening sebagai seorang istri dan Halim sebagai seorang suami. Firasat yang dimiliki Mbah Wening dan Mbah Darmi keduanya mendukung keinginan mereka untuk melaksankan ibadah haji. Tidak ada orang-orang yang menentang kecuali suami Mbah Wening. Sementara niat poligami untuk ibadah sosial masih jadi perdebatan di kehidupan bermasyarakat.

Dalam aspek struktur gangguan (kekacauan), awalnya kedua karakter samasama meminta izin untuk melaksanakan tujuannya. Halim meminta izin berpoligami pada istrinya dan Mbah Wening minta izin naik haji pada suaminya, Kusmin. Kedua film selain mengangkat cerita berlatar agama khususnya Islam, juga membawa isu keluarga, terutama keluarga tradisional Jawa. Baik istri Halim maupun Kusmin menentang niat pasangannya. Kuatnya alasan beribadah di atas kesetiaan terhadap pasangan ini jadi hal yang penting dalam kedua film. 
Tabel 3 Oposisi Biner Gangguan

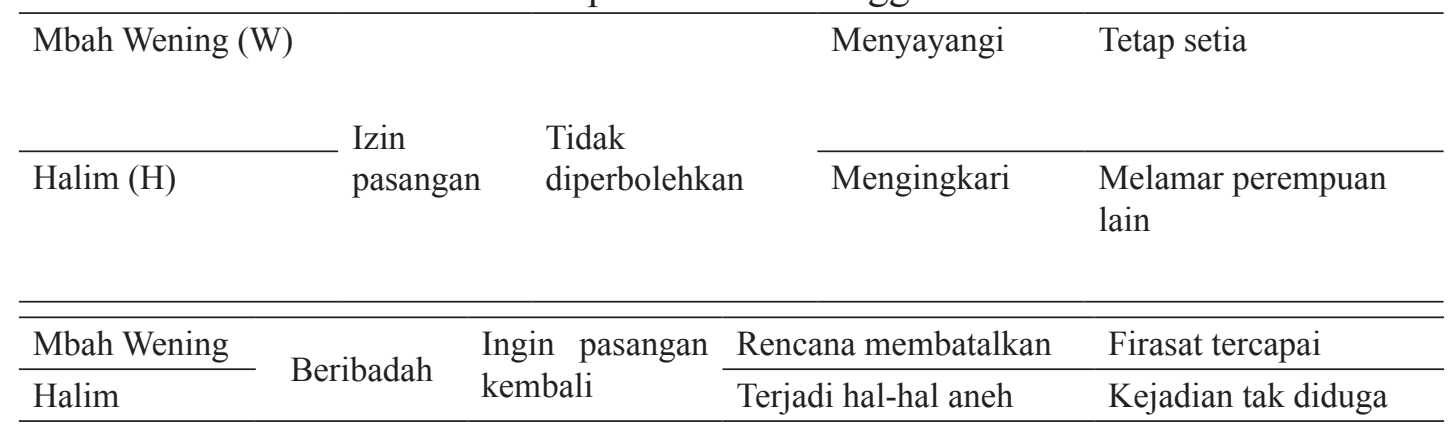

Dari tabel 3 didapatkan adanya kesamaan di antara dua karakter, yakni mereka sama-sama meminta izin pada pasangan masingmasing dan tidak diperbolehkan. Keduanya juga sama-sama melakukan tindakan yang diinginkan untuk beribadah dan pasangannya menginginkan mereka untuk kembali. Oposisi terjadi pada Mbah Wening yang memilih untuk menyayangi Kusmin, sedangkan Halim memilih mengingkari istrinya. Mbah Wening tetap setia, sedangkan Halim malah melamar perempuan lain. Hal ini yang membuat tujuan Mbah Wening tercapai sehingga Halim malah mendapatkan hal-hal yang tidak terduga.

Pada struktur ekuilibrium kedua menuju akhir cerita, berikut adalah susunan miteme secara sintagmatik dan paradigmatik.
Dari uraian paradigmatik dan sintagmatik pada ketiga struktur tersebut dapat ditemukan oposisi biner di antaranya. Meski sama-sama melibatkan permasalahan keluarga dengan niat melaksanakan ibadah, pilihan Mbah Wening untuk tetap setia kepada suaminya berbanding terbalik dengan pilihan Halim untuk tetap berpoligami. Pilihan ini menghasilkan konsekuensi yang oposisi, yakni terjadinya hal-hal yang tidak diduga dan janggal dalam kehidupan Halim. Pemuka agama atau ustad bahkan memperingatkannya untuk berlaku ikhlas atas semua pemberiannya. Berbeda dengan Mbah Wening yang justru didoakan kepergiannya oleh kyai.

Tabel 4 Sintagmatik \& Paradigmatik Ekulibrium 2

\begin{tabular}{lll}
\hline $\begin{array}{l}\text { Kusmin mengizinkan Mbah } \\
\text { Wening naik haji untuk } \\
\text { mewakilkan Mbah Darmi }\end{array}$ & $\begin{array}{l}\text { Mbah Wening didoakan Kyai } \\
\text { sebelum berangkat naik haji }\end{array}$ & Mbah Wening berangkat haji \\
\hline $\begin{array}{l}\text { Halim meminta petunjuk } \\
\text { ustadz akan masalahnya. Halim } \\
\text { diminta ikhlas tapi ia tetap riya' } \\
\text { dalam bersedekah }\end{array}$ & $\begin{array}{l}\text { Banyak kejanggalan saat sholat, } \\
\text { dilakukan Halim }\end{array}$ & $\begin{array}{l}\text { Halim diadili oleh perempuan } \\
\text { Jawa dan perempuan- } \\
\text { perempuan lain yang muncul } \\
\text { sepanjang film }\end{array}$ \\
\hline $\begin{array}{l}\text { Sintagmatik } \\
\text { Mbah Wening }\end{array}$ & $\begin{array}{l}\text { Tabel 5 Oposisi Biner Ekuilibrium 2 } \\
\text { kepergiannya }\end{array}$ & $\begin{array}{l}\text { Sesuai tujuan awal ingin naik } \\
\text { haji }\end{array}$ \\
\hline Halim & Tokoh agama memperingatkan & $\begin{array}{l}\text { Tidak sesuai tujuan awal } \\
\text { ingin poligami, malah terjadi } \\
\text { untuk ikhlas }\end{array}$ \\
& & kejanggalan \\
\hline
\end{tabular}




\section{Konstruksi Keistimewaan dalam Narasi "Munggah Kaji" dan "Ruah"}

Asumsi penelitian ini adalah terdapatnya konstruk keistimewaan lewat film-film produksi Danais. Idealnya, film-film yang diproduksi menggunakan dana yang khusus dialokasikan untuk keistimewaan Yogyakarta merupakan film-film yang juga dapat merepresentasikan keistimewaan Yogyakarta.

Film-film terpilih setidaknya mampu mewujudkan tata nilai budaya masyarakat yang berbasis pada nilai-nilai luhur budaya lokal. Hal ini merujuk pada visi Dinas Kebudayaan DIY sebagai pemrakarsa kompetisi. Dengan misi melestarikan, melindungi, dan mengembangkan aset budaya DIY sebagai upaya mewujudkan jati diri masyarakat serta menjadikan ketahanan budaya sebagai jiwa dan semangat pemerintahan yang katalistik, harapannya DIY dapat menjadi pusat budaya dengan berbagai event budaya nasional dan internasional ${ }^{1}$

Merujuk pada Undang-Undang Nomor 13 Tahun 2012 tentang Keistimewaan Daerah Istimewa Yogyakarta yang tertuang dalam Bab IX tentang Kebudayaan. Tertulis dalam Pasal 31 (1) Kewenangan kebudayaan sebagaimana dimaksud dalam Pasal 7 ayat (2) huruf c diselenggarakan untuk memelihara dan mengembangkan hasil cipta, rasa, karsa, dan karya yang berupa nilai-nilai, pengetahuan, norma, adat istiadat, benda, seni, dan tradisi luhur yang mengakar dalam masyarakat DIY. (2) Ketentuan mengenai pelaksanaan kewenangan kebudayaan sebagaimana dimaksud pada ayat (1) diatur dalam Perdais.

Selain visi dan undang-undang, pembuatan film kompetisi Danais setidaknya juga mengacu pada regulasi pengajuan 1 Seperti tertuang dalam visi dan misi Dinas Kebudayaan DIY (www.jogjafilm.com), diakses pada 12 Maret 2017, pukul 02.00 WIB. proposal. Di situ tertulis bahwa perencanaan film haruslah memuat latar belakang dinamika kebudayaan di DIY. Hal tersebut dapat dikenali melalui indikator-indikator: (a) ruang, antara lain geografis, sosial, ataupun budaya; (b) karakter manusia di Yogyakarta, antara lain cara manusia hidup, bersosialisasi, dan bertahan di Yogyakarta; (c) penguasaan atmosfer sosialbudaya di Yogyakarta; dan (d) ketepatan memilih isu tematik untuk diangkat ke dalam film.

Namun, lewat analisis naratif seperti yang telah diuraikan, hipotesis tersebut tidaklah terbukti. Dari segi aset budaya, struktur dalam pada kedua film tentu tidak dapat merepresentasikan aset budaya DIY karena keduanya memiliki latar agama yang kuat, khususnya hanya Islam. Jati diri masyarakat tentu tidak dapat dilihat dari pemeluk agama Islam meski merupakan mayoritas penduduk Indonesia. Dalam undang-undang, tidak terdapatnya unsur agama juga menjadi alasan yang kuat tidak ditemukannya konstruksi keistimewaan dalam film-film Danais. Tradisi naik haji dan poligami tentu bukanlah kultur yang mengakar dalam masyarakat DIY. Isu satu agama tertentu tidak dapat dijadikan generalisasi terutama dalam representasi masyarakat DIY. Meski narasi pada kedua film dapat diterima, tidak menjadikannya sebuah karya yang dapat mewakili geografis, sosial, budaya, cara hidup, sosialisasi, cara bertahan hidup, penguasaan atmosfer sosial budaya, hingga isu tematik di DIY.

Kesemua uraian tersebut merupakan hasil analisis dari visi Dinas Kebudayaan sebagai penyelenggara kompetisi, UndangUndang Keistimewaan DIY sebagai dasar diadakannya kompetisi dan regulasi proposal sebagai kerangka kurasi film-film produksi Danais. Uraian tersebut merupakan data yang akurat untuk membangun argumentasi tentang tidak ditemukannya konstruksi keistimewaan 
yang terbaca lewat narasi film-film produksi Danais. Artinya, pertanyaan kedua dalam penelitian ini gagal untuk dijawab. Satu-satunya yang mungkin dapat membangun konstruksi keistimewaan adalah kejanggalan yang terjadi pada Ruah dan perempuan Jawa yang keluar dari lukisan untuk mengadili si tokoh utama.

Namun, pertanyaan ketiga terkait bagaimana narasi film dapat mengonstruksi keistimewaan dapat dijawab meski justru bisa menjadi bumerang bagi konsep keistimewaan DIY itu sendiri. Hal ini terjadi karena apa yang ditemukan dari analisis naratif pada kedua film merupakan narasi domestik terkait relasi keluarga, kesetiaan terhadap pasangan demi menjalankan apa yang dianggap benar dalam ajaran agama, meski tidak lazim diterima norma sosial. Jika hal ini yang mengonstruksi keistimewaan DIY, maka aset budaya yang begitu kaya, jati diri masyarakat yang majemuk, ketahanan budaya yang katalistik, nilai pengetahuan, norma, adat, seni, tradisi dan dinamika kebudayaan yang kompleks justru tersimplifikasi dengan sebuah narasi domestik dan religiusitas.

Dalam penelitian ini ditemukan bahwa naratif tidak lepas hubungannya dengan relasi kekuasaan. Kuasa dalam konteks ini dimiliki oleh Dinas Kebudayaan DIY sebagai penyandang dana dan negara Indonesia yang mengalokasikan dana keistimewaan bagi DIY. Kontrol negara (lewat Dinas Kebudayaan DIY) yang besar ikut andil dalam konstruksi narasi dominan apa yang ditampilkannya lewat medium film pendek pemenang kompetisi. Jika konstruksinya tidak mendukung apa yang tertulis dalam kebijakan negara, maka dapat diasumsikan bahwa perubahan konstruksi makna ini dipengaruhi oleh politik dominan yang dianut negara (van Harren, 2012:6).
Artinya, politik dominan negara tidak lepas dari narasi religius dan domestik. Namun berseberangan dengan pemikiran tersebut, pemikiran Krishna Sen perlu digunakan sebagai kritik bagi narasi dominan negara. Film-film dengan konstruksi narasi religius dan domestik produksi kompetisi film Danais ini dapat dibaca sebagai perlawanan konstelasi politik yang dominan di negeri ini Khrisna Sen dalam Guneratne et.al. (2004:147). Artinya, film-film tersebut dapat dimaknai sebagai narasi alternatif dari konstruksi film nasional yang selama ini mendominasi konstruksi perfilman Indonesia konservatif.

\section{SIMPULAN}

Pertanyaan besar penelitian terkait bagaimana narasi film-film kompetisi produksi Dinas Kebudayaan DIY dapat mengonstruksi keistimewaan Yogyakarta tidak dapat sepenuhnya terjawab karena tidak terbacanya konstruksi keistimewaan dari narasi film-film tersebut.

Analisis terhadap cerita dan alur (plot) film "Munggah Kaji” memperlihatkan adanya kemiripan. Analisis terhadap cerita dan alur (plot) film "Ruah" memperlihatkan adanya perbedaan, di mana presentasi alur tidak sama dengan cerita yang ingin disampaikan. Diperlukan pemahaman akan konteks kultural dan pengetahuan akan kepercayaan Jawa (kejawen) untuk dapat memahami cerita film "Ruah". Pada akhirnya, film "Ruah" meninggalkan celah dalam interpretasi ceritanya karena kegagalan memahami alur (plot)-nya yang janggal.

Dalam struktur ekuilibrium (keseimbangan) pertama ini terdapat tiga karakter yang sama-sama taat beribadah dan berpegang teguh pada ajaran agama. Dalam 
tabel oposisi binernya dapat diketahui bahwa ketiga karakter sama-sama senang beribadah meski kondisinya berbeda.

Kedua film selain mengangkat cerita berlatar agama khususnya Islam, juga membawa isu keluarga, terutama keluarga tradisional Jawa. Kuatnya alasan beribadah di atas kesetiaan terhadap pasangan ini jadi hal yang penting dalam kedua film.

Dari uraian paradigmatik dan sintagmatik pada ketiga struktur tersebut dapat ditemukan oposisi biner di antaranya. Meski sama-sama melibatkan permasalahan keluarga dengan niat melaksanakan ibadah, pilihan Mbah Wening untuk tetap setia kepada suaminya berbanding terbalik dengan pilihan Halim untuk tetap berpoligami.

Lewat hasil analisis dari visi Dinas Kebudayaan, Undang-Undang Keistimewaan DIY, dan regulasi proposal sebagai kerangka kurasi film-film produksi Danais, konstruksi keistimewaan dalam film-film Danais tidak ditemukan. Artinya, pertanyaan kedua dalam penelitian ini gagal untuk dijawab.

Apa yang ditemukan dari analisis naratif pada kedua film merupakan narasi domestik terkait relasi keluarga, kesetiaan terhadap pasangan demi menjalankan apa yang dianggap benar dalam ajaran agama, meski tidak lazim diterima norma sosial. Jika hal ini yang mengonstruksi keistimewaan DIY, maka aset budaya yang begitu kaya, jati diri masyarakat yang majemuk, ketahanan budaya yang katalistik, nilai pengetahuan, norma, adat, seni, tradisi dan dinamika kebudayaan yang kompleks justru tersimplifikasi dengan sebuah narasi domestik dan religiusitas.

Kontrol negara (lewat Dinas Kebudayaan DIY) yang besar ikut andil dalam konstruksi narasi dominan apa yang ditampilkannya lewat medium film pendek pemenang kompetisi. Artinya, politik dominan negara tidak lepas dari narasi religius dan domestik. Namun berseberangan dengan pemikiran tersebut, film-film dengan konstruksi narasi religius dan domestik produksi kompetisi film Danais ini juga dapat dibaca sebagai perlawanan konstelasi politik yang dominan di negeri ini (Khrisna Sen dalam Guneratne et.al., 2004:147). Artinya, film-film tersebut dapat dimaknai sebagai narasi alternatif dari konstruksi nasionalistik yang selama ini mendominasi perfilman Indonesia konservatif.

\section{KEPUSTAKAAN}

Ahimsa-Putra, H. S. (2001). Strukturalisme Levi-Strauss: Mitos dan Karya Sastra. Yogyakarta: Galang Press.

Bordwell, D. \& K. T. (2013). Film Art: An Introduction. Tenth Edition. New York: McGraw-Hill.

Eriyanto. (2013). Analisis Naratif: DasarDasar dan Penerapannya dalam Analisis Teks Berita Media. Jakarta: Prenadamedia Group.

Guneratne, A. R. et.al. (2004). Rethinking Third Cinema. London and New York: Routledge.

Kustanto, L. (2015). Analisis Naratif: Kemiskinan dalam Program Reality TV "Pemberian Misterius" di Stasiun SCTV". Jurnal Rekam, 11(2), 109-123.

Nugroho, G., \& Herlina, D. (2015). Krisis dan Paradoks Film Indonesia. Jakarta: Penerbit Buku Kompas.

Suwarto, D. H. dkk. (2015). Pemetaan Pembuat Film Yogyakarta 2015. Yogyakarta: Kajian Perfilman Dinas Kebudayaan DIY.

Todorov, T. (1975). The Fantastic: A Structural Approach to a Literary Genre. Translated by Richard Howard. Ithaca: Cornell University Press.

Van Harren, K. (2012). Contemporary Indonesian Film: Spirits of Reform and Ghosts from the Past. Leiden: KITLV Press. 